\title{
Analyst Following, Corporate Governance And Valuation: Emerging-Market Evidence
}

Minna Yu, Ball State University, USA

\begin{abstract}
This paper considers analyst following as a substitute way of disciplining companies and examines the joint impact of corporate governance and analyst following on valuation in an emerging-market setting. I find that the interaction of analyst following and corporate governance on valuation is not significant for my whole sample. Breaking down the sample to common law versus code law countries indicates that, only for common law countries, the positive relation between the quality of corporate governance and valuation is weaker for companies with greater analyst following than for companies with lower analyst following. This paper joins the stream of research on the monitoring role of financial analysts. It extends Lang et al. (2004) by examining the joint impact of analyst following and corporate governance on valuation with a proxy of overall corporate governance quality. In addition, the finding from this paper suggests that analyst's governance role is more pronounced in common law countries of emerging markets where analyst service is in greater need. The results have implications for investors, analysts and managers in the common law countries of emerging markets that firms with weak corporate governance benefit more from having a high level of analyst following in terms of market valuation.
\end{abstract}

Keywords: analyst following; corporate governance; valuation; emerging markets

\section{INTRODUCTION}

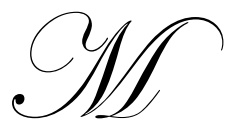

otivated by prior research that both analyst following and corporate governance have a positive effect on firm valuation, this paper examines the joint impact of corporate governance and analyst following on valuation in an emerging-market setting. Corporate governance generally refers to a set of mechanisms through which outside investors protect themselves against expropriation by insiders (La Porta et al. 2000). Prior research finds that firm valuation can be explained by the level of analyst following. Specifically, everything else equal, firms with more analysts following have higher values (Lang et al. 2003).

The empirical evidence regarding the valuation effect of firm-level corporate governance is mixed in developed countries. In U.S., while Gompers et al. (2003) find a positive impact of corporate governance on firm value, Brown and Caylor (2006) and Larcker et al. (2007) document the limited explanatory ability of corporate governance for valuation. In Canada, Klein et al. (2005) find the composite corporate governance scores as published by the Globe \& Mail newspaper do not explain the change in the market value. Also using Canadian companies as their sample, Gupta et al. (2005) find that, although strong shareholder rights, compensation policies and transparent disclosure mechanisms are highly valued by investors, there is no evidence that board composition and independence impact firm value. The insignificant effect of corporate governance can be attributed to the fact that there is little variance in firm-level governance practices among public companies in these countries (Black 2001).

In contrast to the mixed results in developed countries, the positive impact of corporate governance on firm valuation has been consistently documented in emerging markets. For example, Bai et al. (2004) find a positive effect of governance mechanisms on market valuation in China. Kouwenberg (2006) find a significant impact of corporate governance on firm value in Thailand. Black et al. (2006) and Choi et al. (2007) document that an overall corporate governance index is positively associated with market value in Korea. More generally, Klapper and Love 
(2004) and Durnev and Kim (2005) use an emerging market sample and find that companies with better quality corporate governance mechanisms have a higher valuation as measured by Tobin's Q. Because the positive effect of corporate governance on firm value is only significant in emerging markets, this paper examines whether analyst following and corporate governance interact to impact firm value using an emerging-market sample.

My first research hypothesis is that the positive relation between corporate governance and valuation is less pronounced for companies with a higher level of analyst following. Analysts can serve as additional monitoring devices by providing scrutiny and disciplining misbehaving managers (Lang et al. 2004; Knyazeva 2007). In this sense, analyst following is an alternative corporate governance mechanism. Therefore, where analyst following is larger, we should observe that the stand-along effect of good corporate governance on firm value is not as strong. Furthermore, prior research has established that, as information intermediaries, financial analysts play a more active role in common law countries (Chang et al. 2000; Barniv et al. 2005; Yu 2009). Analysts who provide better earnings forecasts will play a better monitoring role. Therefore, my second research hypothesis is that analysts play a more active monitoring role in common law countries in emerging markets.

Using a sample of 753 emerging-market companies over 2001 and 2002, I find that the interaction of analyst following and corporate governance on valuation is not significant for my whole sample. Breaking down the sample to common law versus code law countries indicates that, for common law countries, the positive relation between the quality of corporate governance and valuation is weaker for companies with greater analyst following than for companies with lower analyst following. This relation does not hold for code law countries. Therefore, the monitoring function of analysts can only be observed in countries with stronger investor protection.

This paper extends previous research on the monitoring role of financial analysts by documenting a negative joint impact of analyst following and corporate governance on firm valuation. Lang et al. (2004) find that the impact of ownership structure on valuation is less pronounced when analyst following is greater, thereby suggesting a negative joint impact of ownership structure and analyst following on firm value. However, they only consider one aspect of corporate governance mechanisms: ownership structure and it is desirable to consider the overall quality of corporate governance. In addition, Lang et al. (2004) only focus on the entrenchment effect that the concentrated ownership in family firms creates incentives for controlling shareholders to expropriate wealth from other shareholders. However, there are both the entrenchment effect and the alignment effect of founding family ownership (Claessens and Pan 2002; Wang 2006). The interest of founding firms and other shareholders may be better aligned because of the large blocks of stock owned by family members (i.e., the alignment effect). The caveat of using founding family ownership is that the concentrated ownership in family firms does not necessarily indicate poor corporate governance. By using a measure of the overall corporate governance quality, this paper generalizes the findings of Lang et al. (2004).

Furthermore, the results that the effect of corporate governance on firm value is mitigated by a greater extent of analyst activity are only found in common law countries. These findings are in line with prior studies that analysts have more incentives to play an active role in common law countries (Chang et al. 2000; Barniv et al. 2005).

The rest of the paper proceeds as follows. Section II develops my research hypothesis. Section III describes the model used to test the hypothesis. Section IV summarizes data and sample. Section V presents results and Section VI concludes the paper.

\section{HYPOTHESIS DEVELOPMENT}

The scrutiny of firms' financial performances by analysts puts pressure on managers to work in the interest of investors and increases managerial incentives to maximize firm value. Therefore, by working as information intermediaries, financial analysts play a monitoring role in the market and substitute for corporate governance mechanisms. Prior research has provided evidence on the governance role of financial analysts. For example, Lang et al. (2004) document that the negative effect of lower investor protection ${ }^{\mathrm{i}}$ on valuation is less pronounced when analyst following is greater. Knyazeva (2007) finds that analyst following has a similar effect as governance upon firm behavior. Cheng and Subramanyam (2008) document that the role of analyst following in decreasing a firm's default risk is less pronounced for firms with better corporate governance. McInnis and Collins (2009) provide evidence that firm-level accruals are less manipulative for firms with cash flow forecasts. 
Since corporate governance imposes discipline on misbehaving managers and rewards value creation, the marginal effect of analyst following in presence of better corporate controls will be lower. On the contrary, when the corporate governance is weak, higher analyst following has an incrementally positive effect on valuation. Therefore, I expect a negative joint impact of analyst following and corporate governance on valuation. The hypothesis is stated as follows:

H1: In emerging markets, the positive relation between corporate governance and valuation is less pronounced for companies with a higher analyst following.

Prior research has found that analysts are more active when the country-level investor protection is stronger. Among others, Chang et al. (2000) provide evidence that analyst forecast error and dispersion are lower in common law countries. Barniv et al. (2005) find that, in common law countries, analysts with superior ability and resources have better forecasting performance compared to their peers. These findings lead to the conjecture that analysts play a better governance role in common law countries where investors demand for firm disclosure is greater. Therefore, in these countries, we should observe a more negative joint impact of analyst following and corporate governance on valuation. The second hypothesis therefore is:

H2. In emerging markets, the monitoring role of analysts is more pronounced in common law countries as opposed to in code law countries.

\section{RESEARCH MODEL}

I use the aggregate corporate governance ranking published by CLSA to measure the strength of corporate governance mechanisms (CG). Analyst following (FOLLOWING) is defined as the average number of analysts who issued annual earnings forecasts in I/B/E/S International Database. Since CLSA rankings were published in April 2001 and February 2002, I use the average number of analysts following a company over the period from April 2001 to January 2002 (from February 2002 to January 2003) for the rankings published in April 2001 (February 2002). I also use the individual forecasts in the eleventh month of the fiscal year-end to count the number of analysts following a company as O'Brien and Bhushan (1990) suggest that analyst following levels off in this month. The results are qualitatively unchanged.

To assess the relation among corporate governance, analyst following and valuation, I use a basic OLS regression modified from Lang et al. (2004) in which Tobin's Q is the dependent variable and corporate governance, analyst following and their interaction are the major independent variables.

TOBIN'S $\mathrm{Q}_{\text {it }}=\mathrm{a}_{0}+\mathrm{a}_{1} \mathrm{CG}_{\text {it }}+\mathrm{a}_{2}$ FOLLOWING $_{\text {it }}+\mathrm{a}_{3} \mathrm{CG}_{\text {it }}$ *FOLLOWING $_{\text {it }}+\mathrm{a}_{4}$ SIZE $_{\text {it }}+\mathrm{a}_{5}$ XLIST $_{\text {it }}+$ $\mathrm{a}_{6}$ DEBTS/ASSETS $_{\text {it }}+\mathrm{a}_{7}$ CAPEX/ASSETS $_{\text {it }}+$ error $_{\text {it }}$

Where $\mathrm{i}$ indicates the firm and $\mathrm{t}$ indicates the year;

TOBIN'S Q = the market valuation of assets, computed as total assets less the book value of equity plus the market value of equity divided by book value of assets;

FOLLOWING $=$ the average number of analysts who issued annual earnings forecasts in I/B/E/S in 2001 or 2002;

$\mathrm{CG}=$ the measure of corporate governance mechanisms, calculated as the mean of all seven dimensions of corporate governance reported by CLSA;

SIZE $=$ the $\log$ of total assets;

XLIST $=1$ if the firm has an ADR traded in the United States that requires reconciliation to U.S. GAAP reporting standards;

CG*FOLLOWING $=$ the interaction between CG and FOLLOWING;

DEBTS/ASSETS $=$ the ratio of total debts to total assets;

CAPEX/ASSETS $=$ the ratio of capital expenditures to total assets. 
Following Lang et al. (2004), I include four control variables. SIZE is the log of total assets (in \$U.S. million) and is expected to be negatively associated with Tobin's Q. XLIST is an indicator variable that equals 1 if the company has an ADR traded in the United States that requires reconciliation to U.S. GAAP reporting standards and 0 otherwise. Consistent with Lang et al. (2003), XLIST is expected to be positively associated with Tobin's Q. The ratio of total debts to total assets (DEBTS/ASSETS) controls for the possibility that creditors are able to lessen managerial agency problems or that debt provides valuable tax shields. The ratio of capital expenditures to total assets (CAPEX/ASSETS) is a proxy for a firm's potential investment opportunities. Both DEBTS/ASSETS and CAPEX/ASSETS are expected to have a positive sign. I include two dummy variables to control for time-series auto-correlation. The first dummy variable is 1 if a company has CLSA rankings for both 2001 and 2002 and 0 otherwise. The second dummy variable is 1 if CLSA rankings published in 2001 are used and 0 if CLSA rankings published in 2002 are used. I also add industry and country dummy variables.

Consistent with prior literature (Klapper and Love 2004; Durnev and Kim 2005), $\mathrm{a}_{1}$ is expected to be significant and have a positive sign. Consistent with Lang et al. (2004), $\mathrm{a}_{2}$ is also expected to be significant and positive. Consistent with $\mathrm{H} 1$, I expect $\mathrm{a}_{3}$ to be negative. To test $\mathrm{H} 2$, I decompose the sample based on the legal origin. I expect to find either (1) that $\mathrm{a}_{3}$ is negatively significant in common law countries but not in code law countries or (2) that, if it is negatively significant in both subsamples, then it is larger in the common law countries.

\section{SAMPLE AND DATA}

I use the corporate governance rankings provided by the CLSA survey to measure the overall corporate governance quality in emerging markets. There are 491 and 498 companies from 25 emerging markets in 2001 and 2002, respectively. ${ }^{\text {ii }}$ Seven aspects of corporate governance mechanisms are considered in this survey. "Transparency" (TRAN) is the ability of outsiders to assess the true position of a company. "Discipline" (DSPL) is management's commitment to shareholder value and financial discipline. "Independence" (INDP) is the board of directors' independence from controlling shareholders and senior management. "Accountability" (ACCT) is the accountability of management to the board of directors. "Responsibility" (RESP) is the effectiveness of the board in taking necessary measures in case of mismanagement. "Fairness" (FAIR) is the treatment minority shareholders receive from majority shareholders and management. "Social awareness" (SOCL) is the company's emphasis on ethical and socially responsible behavior. The validity of CLSA as a measure of corporate governance quality has been tested in Durnev and Kim (2005) and Khanna et al. (2006). Prior studies such as Klapper and Love (2004), Bushman et al. (2004), Chen et al. (2005), Ali et al. (2007), and Chen et al. (2009) among others have used this proxy.

The sample selection procedure is provided in Panel A of Table 1. It begins with the 491 and 498 companies surveyed by CLSA in 2001 and 2002 from 25 emerging markets in Asia, Latin America and Eastern Europe, the Middle East and Africa (EEMEA). ${ }^{\text {iii }}$ Because of missing data in I/B/E/S, 117 observations were deleted. Market value of equity and financial statement data including book value of equity, total debts, total assets, and capital expenditures are from Worldscope. XLIST is collected from the Bank of New York Global Equity Investing Depository Receipt Service list. Due to missing data in these two sources, I removed another 119 observations. My final sample is composed of 753 firm-year observations over 2001 and 2002.

In Panel B, I decompose my sample according to legal tradition and countries. My sample includes eight common law countries and eighteen code law countries. There are 426 and 327 observations in the common law and code law partitions, respectively. The average number of analyst following is 5.02 for common law countries and 4.30 for code law countries. This is consistent with Chang et al. (2000) that the average number of analysts following a company is greater when the country's legal protection is stronger. The average corporate governance ranking score is 61.61 for common law countries and 52.79 for code law countries. Also, in line with Lang et al. (2004), the average market value of firms for common law countries is higher than that for code law countries.

Table 2 provides descriptive statistics of all variables. The average number of analysts following a company is 4.66 . The company with the largest analyst following is covered by 16 analysts and the company with the smallest analyst following is covered by 1 analyst. The mean of CLSA corporate governance rankings (CG) is 56.97 with a standard deviation of 13.92 . These rankings range from 10.5 to 93.5 , with a median of 58.60 , the 25 th 
percentile of 48.4, and the 75th percentile of 66.7. The median of XLIST is 0 and the third quartile is 1 , indicating that more than half of the companies are listed in the U.S. stock markets. The mean of Tobin's Q is 1.344, with a standard deviation of 10.439 . It ranges from 0.010 to 2.35 , with a median of 1.21 , the 25 th percentile of 0.98 and the 75th percentile of 1.93. All the variables exhibit considerable variation across the sample.

Table 1

Panel A: Sample selection

Sample selection and descriptive statistics

\begin{tabular}{|l|c|}
\hline & No. of observations \\
\hline Initial sample: & 999 \\
\hline Less: missing data in I/B/E/S & $(127)$ \\
\hline Equals: & 872 \\
\hline Less: missing data in Worldscope & $(119)$ \\
\hline Final sample: & 753 \\
\hline
\end{tabular}

Panel B: Sample breakdown by legal origin and country

\begin{tabular}{|c|c|c|c|c|}
\hline & No. of companies & $\begin{array}{c}\text { Average no. of } \\
\text { analyst following }\end{array}$ & Average CG score & Average Tobin's Q \\
\hline \multicolumn{5}{|c|}{ Common law countries: } \\
\hline Hong Kong & 92 & 7.23 & 61.30 & 1.89 \\
\hline India & 125 & 3.56 & 59.36 & 2.86 \\
\hline Israel & 3 & 1.29 & 39.40 & 1.20 \\
\hline Malaysia & 81 & 6.41 & 61.34 & 1.63 \\
\hline Pakistan & 8 & 1.06 & 34.06 & 1.26 \\
\hline Singapore & 74 & 6.04 & 63.24 & 1.49 \\
\hline South Africa & 50 & 3.23 & 71.07 & 1.82 \\
\hline Sri Lanka & 1 & 3.63 & 50.55 & 0.64 \\
\hline Total (average) & 426 & $(5.02)$ & $(61.61)$ & $(1.85)$ \\
\hline \multicolumn{5}{|c|}{ Code law countries: } \\
\hline Argentina & 6 & 2.93 & 62.85 & 0.90 \\
\hline Brazil & 60 & 5.01 & 60.18 & 1.31 \\
\hline Bulgaria & 1 & 4.00 & 15.40 & 1.78 \\
\hline Chile & 20 & 2.32 & 62.51 & 1.37 \\
\hline China & 36 & 5.93 & 46.44 & 1.20 \\
\hline Colombia & 2 & 1.00 & 54.65 & 0.67 \\
\hline Czech Republic & 4 & 1.76 & 39.30 & 1.06 \\
\hline Greece & 2 & 6.19 & 57.15 & 1.09 \\
\hline Hungary & 3 & 3.14 & 43.23 & 1.14 \\
\hline Indonesia & 29 & 4.25 & 38.10 & 2.06 \\
\hline Korea & 24 & 2.83 & 58.80 & 1.49 \\
\hline Mexico & 15 & 4.17 & 62.51 & 2.00 \\
\hline Peru & 2 & 3.1 & 73.50 & 2.48 \\
\hline Philippine & 32 & 3.90 & 45.21 & 1.24 \\
\hline Poland & 8 & 2.56 & 37.96 & 1.51 \\
\hline Taiwan & 72 & 4.40 & 57.32 & 2.24 \\
\hline Turkey & 23 & 2.98 & 42.04 & 0.95 \\
\hline Venezuela & 1 & 3.57 & 67.10 & 0.95 \\
\hline Total (average) & 327 & $(4.30)$ & $(52.79)$ & $(1.57)$ \\
\hline
\end{tabular}


Table 2

Descriptive statistics

\begin{tabular}{|l|c|c|c|c|c|c|c|}
\hline & Mean & Std dev & Min & 1st quartile & Median & 3rd quartile & Max \\
\hline FOLLOWING & 4.66 & 2.69 & 1 & 2.56 & 4.33 & 6.2 & 16 \\
\hline TRAN & 61.27 & 19.35 & 0 & 50 & 60 & 70 & 100 \\
\hline DSPL & 52.92 & 20.54 & 0 & 33.30 & 55.60 & 66.70 & 100 \\
\hline INDP & 57.83 & 27.12 & 0 & 28.60 & 71.40 & 78.60 & 100 \\
\hline ACCT & 49.11 & 22.04 & 0 & 37.50 & 50.00 & 62.50 & 100 \\
\hline RESP & 51.59 & 21.83 & 0 & 33.30 & 50.00 & 66.70 & 100 \\
\hline FAIR & 64.96 & 27.20 & 0 & 38.90 & 77.80 & 88.90 & 100 \\
\hline SOCL & 69.84 & 21.76 & 0 & 50.00 & 66.70 & 83.30 & 100 \\
\hline CG & 56.97 & 13.92 & 10.5 & 48.4 & 58.60 & 66.7 & 93.5 \\
\hline CG*FOLLOWING & 276.1 & 188.5 & 18.9 & 127.4 & 241.9 & 373.4 & 611.6 \\
\hline SIZE & 10.42 & 2.75 & 4.11 & 7.83 & 9.89 & 64.8 & 80.48 \\
\hline XLIST & 0.31 & 0.46 & 0 & 0 & 0 & 1 & 1 \\
\hline DEBTS/ASSETS & 0.45 & 0.19 & 0 & 0.34 & 0.49 & 0.68 & 1.56 \\
\hline CAPEX/ASSETS & 0.08 & 0.07 & 0 & 0 & 0.04 & 0.08 & 0.42 \\
\hline TOBIN's Q & 1.344 & 10.44 & 0.01 & 0.98 & 1.21 & 1.93 & 2.35 \\
\hline
\end{tabular}

Variable definitions:

FOLLOWING is the average number of analysts who issued annual earnings forecasts in I/B/E/S in 2001 or 2002;

TRAN is the ability of outsiders to assess the true position of a company;

DSPL is management's commitment to shareholder value and financial discipline;

INDP is the board of director's independence from controlling shareholders and senior management;

ACCT is the accountability of management to the board of directors;

RESP is the effectiveness of the board in taking necessary measures in case of mismanagement;

FAIR is the treatment minority shareholders receive from majority shareholders and management;

SOCL is the company's emphasis on ethical and socially responsible behavior;

CG is the measure of corporate governance mechanisms, calculated as the mean of all dimensions (TRAN, DSPL, INDP, ACCT, RESP, FAIR and SOCL);

CG*FOLLOWING is the interaction between CG and FOLLOWING;

SIZE is the log value of total assets;

XLIST is an indicator variable that equals 1 if the firm has an ADR traded in the United States that requires reconciliation to U. S. GAAP reporting standards;

DEBTS/ASSETS is total debts divided by total assets;

CAPEX/ASSETS is capital expenditures divided by total assets;

TOBIN's Q is computed as total assets less the book value of equity plus the market value of equity divided by book value of assets.

\section{RESULTS}

Table 3 provides simple correlations between variables. As expected, analyst following is positively correlated with the quality of corporate governance in both Pearson (correlation coefficient $=0.213$ ) and Spearman correlations (correlation coefficient $=0.204$ ). Consistent with Lang et al. (2003), analyst following is positively related with Tobin's Q in both Pearson and Spearman correlations with correlation coefficients of 0.120 and 0.109, respectively. Consistent with prior research that documents the positive valuation effect of corporate governance, CG is positively related with Tobin's Q in Spearman correlation. However, contra-intuitively, CG is negatively related with Tobin's Q in Pearson correlation.

Table 4 presents empirical results of Model (1). Both CG and FOLLOWING are positively associated with Tobin's Q. The positive relation between CG and Tobin's Q is consistent with Klapper and Love (2004) and Durnev and Kim (2005). The positive relation between FOLLOWING and Tobin's Q is in line with Lang et al. (2004). However, inconsistent with my prediction, the interaction term CG*FOLLOWING is not significant. Therefore, evidence from the whole emerging market sample does not support $\mathrm{H} 1$. 
Table 3

Simple correlations

\begin{tabular}{|l|c|c|c|c|c|c|c|}
\hline & FOLLOWING & CG & SIZE & XLIST & DEBTS/ASSETS & CAPEX/ASSETS & TOBIN'S Q \\
\hline \multirow{3}{*}{ FOLLOWING } & & 0.213 & -0.091 & 0.166 & -0.016 & 0.040 & 0.120 \\
& & $(0.01)$ & $(0.01)$ & $(0.01)$ & $(0.66)$ & $(0.26)$ & $(0.02)$ \\
\hline \multirow{3}{*}{ CG } & 0.204 & & -0.257 & 0.037 & -0.039 & -0.005 & -0.115 \\
SIZE & $(0.01)$ & & $(0.01)$ & $(0.26)$ & $(0.25)$ & $(0.88)$ & $(0.01)$ \\
\hline & -0.089 & -0.241 & & 0.114 & 0.389 & -0.007 & -0.318 \\
XLIST & $(0.013)$ & $(0.01)$ & & $(0.01)$ & $(0.01)$ & $(0.84)$ & $(0.01)$ \\
\hline DEBTS/ASSETS & 0.150 & 0.024 & 0.135 & & -0.037 & -0.022 & -0.081 \\
& $(0.01)$ & $(0.46)$ & $(0.01)$ & & $(0.26)$ & $(0.51)$ & $(0.09)$ \\
\hline CAPEX/ASSETS & -0.033 & -0.010 & 0.390 & -0.030 & & -0.010 & -0.119 \\
& $(0.35)$ & $(0.75)$ & $(0.01)$ & $(0.36)$ & & $(0.77)$ & $(0.01)$ \\
\hline TOBIN'S Q & 0.026 & 0.011 & -0.169 & 0.084 & -0.254 & & 0.136 \\
& 0.109 & 0.169 & -0.152 & -0.058 & -0.160 & 0.304 & $(0.01)$ \\
\hline
\end{tabular}

Pearson correlation is above and Spearman correlation is below the diagonal. $\mathrm{p}$ values based on two-tailed tests are in parentheses.

Table 4

The association among analyst following, corporate governance and valuation

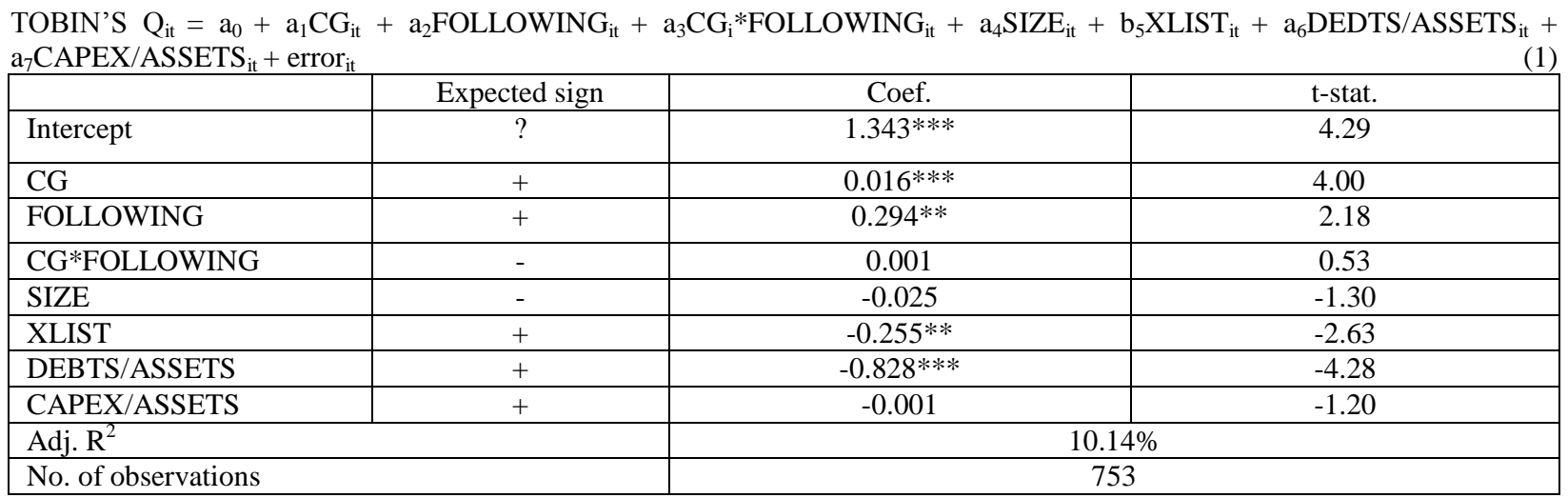

White adjusted t-statistics are provided.

$* \mathrm{p}<0.05$

$* * \mathrm{p}<0.01$

$* * * \mathrm{p}<0.001$

To test H2, I rerun the regression partitioning my sample companies based on their legal origins. Table 5 presents the results of Model (1) separately for common law and code law subsamples. For companies with a code law origin, neither analyst following nor corporate governance is found to be associated with Tobin's Q. Furthermore, contrary to my expectation, the interaction between corporate governance and analyst following is positively associated with Tobin's Q. This finding suggests that firm valuation is positively related to corporate governance only when there is a higher level of analyst following. Stated differently, everything else equal, only those heavily followed firms with good corporate governance enjoy higher valuations. Therefore, analyst following does not serve as a substitute way of disciplining companies in code law countries. 
Table 5

The association among analyst following, corporate governance and valuation partitioned by legal origin

TOBINS's $\mathrm{Q}_{\mathrm{it}}=\mathrm{a}_{0}+\mathrm{a}_{1} \mathrm{CG}_{\mathrm{it}}+\mathrm{a}_{2}$ FOLLOWING $_{\mathrm{it}}+\mathrm{a}_{3} \mathrm{CG}_{\mathrm{it}}$ FOLLOWING $_{\mathrm{it}}+\mathrm{a}_{4}$ SIZE $_{\mathrm{it}}+\mathrm{a}_{5}$ XLIST $_{\mathrm{it}}+\mathrm{a}_{6}$ DEBTS/ASSETS $_{\mathrm{it}}+$

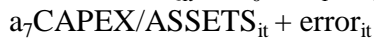

\begin{tabular}{|c|c|c|c|c|c|}
\hline & & \multicolumn{2}{|c|}{ Common law } & \multicolumn{2}{|c|}{ Code law } \\
\hline & Expected sign & Coef. & t-stat. & Coef. & t-stat. \\
\hline Intercept & $?$ & $1.231 * *$ & 2.48 & $1.018 * *$ & 2.62 \\
\hline $\mathrm{CG}$ & + & $0.024 * * *$ & 3.98 & 0.007 & 1.28 \\
\hline FOLLOWING & + & $0.503 * *$ & 2.66 & -0.051 & -0.26 \\
\hline CG*FOLLOWING & - & $-0.001 *$ & -1.79 & $0.003 * *$ & 2.67 \\
\hline SIZE & - & $-0.097 * *$ & -2.40 & 0.023 & 1.03 \\
\hline XLIST & + & $-0.294 *$ & -2.02 & $-0.225^{*}$ & -1.84 \\
\hline DEBTS/ASSETS & + & $-0.581^{*}$ & -1.99 & $-0.819 * * *$ & -3.35 \\
\hline CAPEX/ASSETS & + & $5.215 * * *$ & 5.05 & -0.001 & -1.46 \\
\hline \multicolumn{2}{|l|}{ Adj. $\mathrm{R}^{2}$} & \multicolumn{2}{|c|}{$16.42 \%$} & \multicolumn{2}{|c|}{$10.18 \%$} \\
\hline Chow-F tests & & \multicolumn{2}{|c|}{$6.73 * * *$} & & \\
\hline No. of observations & & & & \multicolumn{2}{|c|}{327} \\
\hline
\end{tabular}

White adjusted t-statistics are provided.

$*: \mathrm{p}<0.05$

$* *: \mathrm{p}<0.01$

$* * *: \mathrm{p}<0.001$

For the subsample of common law countries, both CG and FOLLOWING are positively associated with Tobin's Q. The coefficient on CG is 0.024 and the t-statistic is 3.98. The positive effect of corporate governance on Tobin's Q is consistent with Klapper and Love (2004) and Durnev and Kim (2005) that better-governed companies are highly valued in emerging markets. The coefficient on FOLLOWING is 0.503 , with a t-statistic of 2.66. This finding is consistent with Lang et al. (2004) that the market valuation is higher for heavily followed firms. More importantly, the interaction between CG and FOLLOWING is negative and significant (coefficient $=-0.001$, $\mathrm{t}-$ statistic $=-1.79$ ). This finding supports my hypothesis that the association between valuation and the level of analyst following is conditioned on the quality of corporate governance, with the positive association between governance and valuation being weaker for companies with a higher analyst following. The adjusted $\mathrm{R}^{2}$ is higher for the common law subsample than for the code law subsample. The Chow-F statistic is 6.73, significant at the 0.01 level. This finding supports the conjecture that firm-level corporate governance and country-level investor protection are complements. In other words, firm-level improvement in corporate governance is particularly effective when the legal regime of the country offers a higher level of protection for shareholders. Therefore, $\mathrm{H} 2$ is supported in that the monitoring role of analysts is observed in common law countries but not in code law countries.

Lang et al. (2004) find a stronger joint effect of ownership structure and analyst following on valuation in code law countries, as opposed to common law countries. On the contrary, I find that the negative joint impact of corporate governance and analyst following only significant in common law countries. One potential reason for this difference is that Lang et al. (2004) use ownership structure as a proxy for the strength of corporate governance. However, ownership structure is only one dimension of corporate governance mechanisms. In addition, as Wang (2006) suggests, ownership structure is not a good proxy for corporate governance. The different results could also be attributed to our sample selections. Only one third of Lang et al. (2004)'s sample companies are from emerging markets. Therefore, their results are primarily reflective of developed countries and my results using the emerging market sample are specific to developing countries.

To rule out the possibility that the results are due to autocorrelation, I eliminate companies with corporate governance rankings in both years and use the subset of companies that only have rankings for either 2001 or 2002. There are 382 companies in this subsample, 207 companies with a common law origin and 175 companies with a code law origin. These sensitivity-test results (available on request) are unchanged from main tests. 


\section{CONCLUSIONS}

This paper examines the joint impact of corporate governance and analyst following on valuation in an emerging-market setting. Corporate governance strength is measured by the ratings compiled by Credit Lyonnais Securities Asia (CLSA) based on a wide variety of corporate governance characteristics, including those associated with disclosure, independence of board of directors, how responsible and fair the board of directors is, etc. I predict that the positive relation between corporate governance and valuation is less pronounced when a company has a higher level of analyst following. This hypothesis is supported in common law countries but not in code law countries. In line with Lang et al. (2004), Knyazeva (2007), Cheng and Subramanyam (2008), and McInnis and Collins (2009), this finding provides supporting evidence on analysts' monitoring role. In addition, the finding from this paper suggests that analyst's governance role is more pronounced in common law countries of emerging markets where analyst service is in greater need.

The results have important implications for investors, analysts and managers in emerging markets that, relative to firms with strong corporate governance, firms with weak corporate governance benefit more from having a high level of analyst following. This paper also implies that the governance role financial analysts play in the emerging economies varies by institutional factors. Specifically, when firm-level corporate governance is lower, higher analyst following is only valued in common law countries.

This paper is subject to limitations due to data availability. First, CLSA rankings are only provided for one or two years for my sample firms. Second, this paper provides empirical evidence primarily for the largest emerging-market companies. Therefore, caution should be taken when interpreting the regression results obtained with this sample. Future research is warranted to test the hypotheses with a longer time period and a larger sample size.

\section{REFERENCES}

1. Bai, C., Q. Liu, J. Lu, S. Frank, and J. Zhang. 2004. Corporate governance and market valuation in China. Journal of Comparative Economics 32 (December): 599-616.

2. Barniv, R., M. Myring, and W. Thomas. 2005. The association between the legal and financial reporting environments and forecast performance of individual analysts. Contemporary Accounting Research 22 (December): 727-758.

3. Black, B. 2001. Does corporate governance matter? A crude test using Russian data. University of Pennsylvania Law Review 149 (June): 2131-2150.

4. Black, B., H. Jang, and W. Kim. 2006. Does corporate governance predict firms' market values? Evidence from Korea. Journal of Law, Economics, \& Organization 22 (October): 366-413.

5. Brown, L., and M. Caylor. 2006. Corporate governance and firm valuation. Journal of Accounting and Public Policy 25 (July/August): 409-434.

6. Chang, J., T. Khanna, and K. Palepu. 2000. Analyst activity around the world. Working paper, Harvard Business School.

7. Cheng, M., and K. Subramanyam. 2008. Analyst following and credit ratings. Contemporary Accounting Research 25(Winter): 1007-1044.

8. Choi, J., S. Park, and S. Yoo. 2007. The value of outside directors: Evidence from corporate governance reform in Korea. Journal of Financial and Quantitative Analysis 42 (December): 941-962.

9. Claessens, S., and J. Pan. 2002. Corporate governance in Asia: A survey. International Review of Finance 3 (June): 71-103.

10. CLSA Emerging Markets. 2001. Saints and sinners: Who's got religion? Hong Kong.

11. CLSA Emerging Markets. 2002. Make me holy... But not yet! Hong Kong.

12. Durnev, A., and H. Kim. 2005. To steal or not to steal: Firm attributes, legal environment, and valuation. The Journal of Finance 60 (June): 1461-1493.

13. Fan, J., and T. Wong. 2002. Corporate ownership structure and the informativeness of accounting earnings in East Asia. Journal of Accounting and Economics 33 (January): 401-425.

14. Gompers, P., J. Ishii, and A. Metrick. 2003. Corporate governance and equity prices. Quarterly Journal of Economics 118 (February): 107-115. 
15. Gul, F. and H. Qiu. 2002. Legal protection, corporate governance and information asymmetry in emerging financial markets. Working paper, City University of Hong Kong.

16. Gupta, P., D. Kennedy and S. Weaver. 2005. Corporate governance scores, Tobin's Q and equity prices: Evidence from Canadian capital markets. Working paper, Lehigh University.

17. Khanna, T., J. Kogan, and K. Palepu. 2006. Globalization and similarities in corporate governance: A cross-country analysis. Review of Economics and Statistics 88 (February): 69-90.

18. Klapper, L., and I. Love. 2004. Corporate governance, investor protection, and performance in emerging markets. Journal of Corporate Finance 10 (November): 703-728.

19. Klein, P., D. Shapiro, and J. Young. 2005. Corporate governance, family ownership and firm value: the Canadian evidence. Corporate Governance: An International Review 13 (November): 769-784.

20. Knyazeva, D. 2007. Corporate governance, analyst following and firm behavior. Working paper, New York University.

21. Kouwenberg, R. 2006. Does voluntary corporate governance role adoption increase firm value in emerging markets? Evidence from Thailand. Working paper, Mahidol University.

22. La Porta, R., F. Lopez-de-Silanes, A. Shleifer, and R. Vishny. 2000. Investor protection and corporate governance. Journal of Financial Economics 58 (October/November): 3-27.

23. Lang, M., K. Lins, and D. Miller. 2003. ADRs, analysts, and accuracy: Does cross listing in the United States improve a firm's information environment and increase market value? Journal of Accounting Research 41 (May): 317-345.

24. Lang, M., K. Lins, and D. Miller. 2004. Concentrated control, analyst following and valuation: Do analysts matter most when investors are protected least? Journal of Accounting Research 42 (June): 589-622.

25. Larcker, D., S. Richardson, and I. Tuna. 2007. Corporate governance, accounting outcomes, and organizational performance. Accounting Review 82 (July): 963-1008.

26. McInnis, J. and D. Collins. 2009. The effect of cash flow forecasts on accruals quality and benchmark beating. Working paper, University of Texas at Austin.

27. O'Brien, P. and R. Bhushan. 1990. Analyst following and institutional ownership. Journal of Accounting Research 28 (Supplement): 55-82.

28. Wang, D. 2006. Founding family ownership and earnings quality. Journal of Accounting Research 44 (June): 619-656.

\section{Endnote:}

\footnotetext{
${ }^{\mathrm{i}}$ Corporate governance is measured by the presence of concentrated family/management control in Lang et al. (2004).

${ }^{i i}$ In response to the growing demand by investors for independent assessments of corporate governance mechanisms, CLSA Emerging Markets, a provider of brokerage and investment banking services in the emerging markets of Asia, Latin America and Europe, released a comprehensive report on corporate governance entitled "Saints \& Sinners: Who's Got Religion?" in April 2001 and an updated survey entitled "Make me holy...but not yet!" in February 2002. The CLSA report includes corporate governance (CG) rankings on 495 companies in 25 countries. The sample is selected based on two criteria: company size and investor interest.

iii The major economies of EEMEA are Russia, Turkey, Poland, Saudi Arabia, Greece and South Africa, most of which (except Saudi Arabia) are considered as emerging economies of the world.
} 